\title{
Problems and Prospects of Information and Communication Technologies Application in Agriculture in Nigeria. By
}

Z. Abdulsalam*, Akinola M.O. and Buwanhot, Y.Y.

Department of Agricultural Economics and Rural Sociology, Faculty of Agriculture, Ahmadu Bello University, Zaria

*All correspondences to: zakabdul2001@yahoo.co.uk

\begin{abstract}
Information and communication technology (ICT) has become a veritable tool being used to solve agricultural related problems ranging from site selection to sale of farm produces in many parts of the world. In Nigeria, the application of ICT in farm enterprises is not widespread. This research was designed to assess the prospects and problems/factors limiting the awareness and usage of ICT in Nigerian agriculture. Also, it identified and described the available ICT technologies in Nigeria. Primary data were obtained from the respondents through the use of structured questionnaire. The information collected was analyzed by the use of descriptive statistics and multiple regression technique. Results of the analysis showed that the educated respondents were more aware and made use of ICTs than those with out formal education at 5\% level of probability. The major problems identified with regards to the usage of ICTs by the respondents include poor access to ICT facilities, low sensitization on available ICTs, poor source of power supply and high cost of software and hardware. It was therefore recommended that government and NGOs should collaborate to improve sensitization drive, to not only increase awareness but also to encourage application, improve on power supply, provide accessible network at cheaper price, translate technology to local languages and more training on ICT usage in the agroindustry.
\end{abstract}

\section{Introduction}

Information can be defined as knowledge communicated by others or obtained from investigation study or instruction. It could be the process by which the form of an object of knowledge is impressed upon the apprehending mind so as to bring about a state of knowing (Merriam-Webster, 1993). Technology on the other hand is the science of application of knowledge to practical purposes. Technology determines the quality of life of a people and the overall status of their nation (Momah, 1999).

Information has been the driving force to so many human activities in search of developing one-self, which has created a basis for the need to know. It has been said that "Ignorance is a disease and knowledge is its cure, which is achieved by obtaining information" (Momah, 1999). This therefore brought about the birth of ICT.

ICT has since been the dawn of a new day in several countries among professions/professionals that are venturing into adopting it. This has led to the globalization of all human activities. We are now moving towards a global knowledge society where information skills and competence become the driving force of social and economic development. Recent studies seem to agree that the observed changes in growth patterns in some countries are largely the result of the ICT revolution. In particular, it is argued that countries that have developed an ICT - producing industry, and/or where other industries have been quick in adopting highly productive ICT equipments, have been able to shift to highest output and productivity growth paths. Furthermore, it has been postulated that:

i. Information technology is becoming the main engine of economic growth. It will displace oil, just as oil displaced steel in the second half of the last century, as the main engine of the economic growth;

ii. Production will increasingly be knowledge based, and

iii. Increasing advances in ICT, especially in the telecommunications sectors, will quicken the pace of globalization of trade. (Danial, 2006).

As a result of the opportunities offered by the ICTs, some socio-economic and technical related problems in agriculture in some countries are now being solved using the knowledge reserve opened by the availability of the ICTs. The Nigerian agricultural sector is therefore expected not to be 
exception in these advances. For these reasons, the following research questions need to be answered:

i. What are the factors or problems limiting the use of ICTs in the agricultural sector?

ii. Does ICT have any beneficial prospects in the Nigerian agricultural sector?

iii. What are the socio-economic characteristics of the respondents and how do they affect level of ICTs awareness and application?

iv. What are the various ICTs available to stakeholders in agriculture in Nigeria?

In view of these, the objectives of this study are therefore to:

i. identify and describe the available ICTs applicable in the Nigerian agriculture,

ii. describe the socio-economic characteristics of the respondents and assess how they affect ICTs awareness and application, and

iii. outline the problems and prospects of the usage of ICTs in Nigerian agriculture.

\section{The ICT and Agriculture.}

ICT is an indispensable part of the contemporary world. In fact, culture and society have to be adjusted to meet the challenges of the knowledge age. The pervasiveness of ICT has resulted in a political, social and economic transformation as well as eventuated in a network society organized around ICT. In order to husband the potentials of ICT, most nations of the world have evolved national ICT policies, to serve as a framework for ICT integration in all facets of the society. African countries, and particularly Nigeria, are not exceptions to this practice.

The field of agriculture has not been unaffected by the penetrating influence of ICT. In concrete context, ICT can enhance agriculture through its dynamic, interactive and engaging content; and it can provide real opportunities for individualized instruction. ICT has the potential to accelerate, enrich and deepen skills; motivate and engage students in learning; helps to relate farm experiences to work practices; helps to create economic viability for workers; contribute to radical changes in agriculture; strengthen agriculture, and also provide opportunities for connection between the farm and the world. ICT would make agriculture more effective and productive, thereby engendering a variety of tools to enhance and facilitate farmers' professional activities (Kirschner and Woperies, 2003).

In research, ICT provide opportunities for farmers to communicate with one another through email, mailing lists, and chat rooms. It also provides a quicker and easier access to more extensive and current agricultural information. Furthermore, it can provide researchers with a steady avenue for the dissemination of research reports and findings (Yusuf, 2006).

The marketing sector is not left out in the application of ICT. Market information facilitates marketing function and market intelligence is essential for a smooth, efficiently operating marketing system. Although adequate information is lacking in various sectors of the economy which may include information on current market prices, marketing channels utilized, current and potential production levels, product acceptability by consumers, packaging, handling agencies and government policies affecting the production and marketing of specific products, ICT has made it possible to have some Nigerian agricultural market information services available on the internet. For example, RUSEPMIS (http://www.rusep.org/mis/) RUSEP is one of the pioneer marketing information services in Nigeria, which started with four pilot states (Adamawa, Abia, Oyo and Katsina). Data of 21 commodities are collected on a weekly basis and analyzed from these states. Information is provided to producers, processors, industrialists and traders based on their market needs. Information such as real-time market price(http://www.rusep.org/mis/compare2.asp),

business opportunities (http://www.rusep.org/mis/businessopport.htm), items available for sale (http://www.rusep.org.mis/buyres.asp),

radiobroadcast

http://www.rusep.org/mis/broadcast.htm),

of

commodities in the states are made available on the internet. (Fabiyi, 2004).

Immense advantages are promised by globalization through ICT, but it is sometimes wrongly imagined that there are no drawbacks. Globalization is unfortunately a zero-sum game which has the capability of producing the win-win outcome that is popularly canvassed. However, this can only be achieved if all countries are able to interrelate with 
one another individually from a position of strength (Ariyo, 1999).

\section{Research Methodology}

\section{Study Area}

Nigeria is the most populated country in Africa with an estimated population figure of over 120 million (Boroffice, 2004) and occupies a landmass of about 924,000 square kilometers. Nigeria is located between latitude $3.5^{\circ} \mathrm{N}$ and $14.5^{\circ} \mathrm{N}$ and longitude $3{ }^{\circ} \mathrm{E}$ and $14^{\circ} \mathrm{E}$. Nigeria has a vast geographical area of contracting forms, climatic condition and vegetation belts. It is bordered in the South by the Atlantic Coastline which includes the eastern sector of the gulf of guinea in the north, east and west by the neighbouring Niger, Cameroon, Chad and Benin Republic respectively.

Nigeria has two rivers, Benue and Niger. Its local time is an hour ahead of GMT and has a tropical and sub-tropical climate. Her seasons are mostly dry and wet (NDA, 2001). The major occupation in Nigeria is agriculture. This is because over half of the population engages in livestock production, forestry, fishery production and crop production. The total cultivable land in the country is about 71 million hectares (Boroffice, 2004).

\section{Sampling Procedure and Data Collection}

The purposive sampling technique was employed to select both the Institute for Agricultural Research (IAR) and Dakace Village respectively. Dakace was selected because it is one of the villages that IAR frequently test and introduce innovations. Also, I.A.R was selected because it is a research institute and therefore it is expected that the researchers are aware of, and apply ICTs.

Twenty (20) researchers were randomly selected from the IAR, which represents $40 \%$ of the population of 50 researchers that were available at the time of sampling. Also, twenty (20) farmers were randomly selected from Dakace village.

Primary data were used for the study. Data collection was done using structured questionnaire. The information collected includes the socioeconomic variables of the farmers and researchers such as educational status, membership of association and sex of the respondents. Other variables include source(s) of information, application of ICT, frequency of usage, the level of awareness of ICT technologies and problems and prospects of ICT usage in agriculture.

\section{Analytical Techniques}

In order to achieve the objectives of the study, descriptive statistics and multiple regression analysis were used to analyze the data. The implicit regression analysis model for the study is specified as follows:

\begin{tabular}{|c|c|c|}
\hline \multicolumn{3}{|c|}{$\mathrm{Y}=\mathrm{F}\left(\mathrm{X}_{1}, \mathrm{X}_{2}, \mathrm{X}_{3}, \mathrm{X}_{4}, \mathrm{X}_{5}, \mathrm{e}\right)$} \\
\hline \multicolumn{3}{|c|}{ Where, } \\
\hline $\mathrm{Y}$ & $=$ & level of awareness of ICT \\
\hline $\mathrm{X}_{1}$ & $=$ & Sex of the respondents \\
\hline $\begin{array}{c}\mathrm{X}_{2} \\
\text { resp }\end{array}$ & $\begin{array}{l}= \\
\text { ents }\end{array}$ & Educational status \\
\hline $\mathrm{X}_{3}$ & $=$ & $\begin{array}{l}\text { Primary occupation of the } \\
\text { respondents }\end{array}$ \\
\hline $\mathrm{X}_{4}$ & $=$ & Membership of association \\
\hline $\mathrm{X}_{5}$ & $=$ & Access to sources of information \\
\hline & $=$ & error term \\
\hline
\end{tabular}

\section{Definition Variables}

Awareness of ICT technology - This is the extent of knowledge of the respondents about the ICT technologies available. The more the level of awareness of a technology, the more the interest to understand it and participate by trying it out, in accordance with Rogers's adoption principle (Rogers, 1995).

Sex - This is the extent to which the respondents are segregated based on gender. The more segregated they are based on gender the more difficult it is for information to spread among them equally. It is expected that males are more predisposed to change than females due to sociocultural barriers (Kaul, 1991).

Educational status - This is the extent to which the respondents have attained a level of literacy. It is expected that those who are able to read and write would be more aware of the ICTs than those who have no formal educational status.

Primary occupation - This refers to the main source of income of the respondents. It shows the extent to which the respondents are engaged in agriculture and related activities. It is expected that respondents who are more engaged in agriculture will be better aware of technologies associated with agriculture than those who are not engaged in agriculture as their primary occupation.

Membership of association - Association is a collection of people with a common purpose. It is expected that as members of an association, an increase in the level of awareness about 
technologies relevant to the association by members exists.

Access to sources of information - This is the extent to which the respondents have access to sources of information. It is expected that the more access the respondents have to sources of information the more the level of their awareness about ICT technologies.

\section{Results and Discussions}

\section{Available ICTs in Nigeria}

Global system of mobile communications (GSM) has brought about a new era of communication and thereby enhancing information transfer among people in the country. This first started when a significant leap was made when the government in 1999 issued a document on telecommunications development strategy and investment opportunities in Nigeria.

In April 1999, the government of Nigeria established the National Space Research and Development Agency (NASRDA) with a mandate to consolidate all space and technology-related activities in order to make a greater impact on development efforts in Nigeria. An embarkment on a technical initiative by building know-how amongst indigenous engineers and scientists in space technology, by the national space research and development agency (NASRDA), crystallized in the building and launch of the first Nigerian satellite called Nigeria sat-1.

This satellite, in constellation with other satellites takes photos/images of Nigerian environment and sends them back for use in various areas of socioeconomic development including agriculture. Potential areas of data utilization from Nigerian sat-1 include;

i. Documentation of pre, on-time and post (flooding) events with possibility for early warning, planning, evacuation, refuge displacement location and relief management.

ii. Mapping land use planning and management e.g. flood plains suitable for rice cultivation.

iii. Crop inventory and yield forecasting.

iv. Mapping, investigating and monitoring pest infestation including desert locust and quella birds risks. v. Availability of readily accessible data for research and development.

vi. Instructional/teaching aid for secondary institutions

vii. Remote sensing education or capacity building for the use of earth observation data (Boroffice, 2004).

Some other ICT technologies which are of importance to agriculture in include:

i. Global Positioning Systems (GPS): To locate and define spatial features or activities that contributes to the quality of site-specific practices.

ii. Geographical Information Systems (GIS): A system of creating, storing, analyzing and managing spatial data, mapping and associated attributes.

iii. Remote Sensing (RS): Deals with the detection and measurement of phenomena with devices sensitive to electromagnetic energy.

iv. Variable Rate Technology (VRT): It is a site-specific management practice involving variable rate control (VRC) of seeding, spreading and spraying operations to more accurately target inputs in areas where they are most valuable.

v. Yield Monitoring Technology (YMT): for recording crop productivity as an historical database fro crop management.

vi. E-Commerce in Agriculture: A technology of buying and selling of farm produce via the internet (electronic market).

vii. Market Information Technology (MIT): It involves the application of information technology to achieve the marketing functions associated with produce sales and purchase. (Rains and Thomas, 2000).

\section{Socio-Economic Characteristics and their Effect} on Awareness and Application of ICTs

\section{Socio-Economic Characteristics}

Some of the important socio-economic characteristics of the farmers considered were sex, level of education, major occupation, membership of cooperative, and source of information.

\section{a) Sex distribution}

It was found that $90 \%$ of the respondents in IAR were male while $10 \%$ of the respondents were female. Also, 95\% of the respondents in Dakace were male while $5 \%$ were female. This implies 
that males are more in wage-based employments than females.

\section{b) Educational status}

Level of education attained is an important factor that determines the ability of a person to understand policies or programmes that affect his/her profession, to accept and adopt innovations, to make decisions on production, sale and enterprise selection, access to formal credit sources, etc (Abdulsalam, 1997). It was found that all the respondents in the I.A.R were educated with $100 \%$ of them attaining university education. In Dakace, only $15 \%$ of the respondents had attained either secondary or adult education while the majority of the respondents $(85 \%)$ had no formal education.

The belief is that respondents who had attained some level of formal education, no matter how rudimentary would better appreciate the demands of modern farming. The ability to read and write as pointed out by Adesimi (1981) reduce substantially the cost of obtaining new technical and economic information. In other words, a respondent's ability to read/write increases his/her awareness on modern technology. On the contrary, limited education could stand as an obstacle to awareness of ICTs.

\section{c) Major occupation}

The study shows that $100 \%$ of the respondents in I.A.R are civil servants (lecturers, researchers). Out of this, $45 \%$ of the respondents in I.A.R are lecturers, $25 \%$ are researchers while $30 \%$ of them are involved in both lecturing and research as their major occupation. This implies that the importance of research in agriculture is still being cherished and is being carried out by respondents with high level of educational status as a major occupation.

In Dakace, $95 \%$ of the respondents are full-time farmers while the rest $5 \%$ are part-time farmers. This implies that majority of the respondents in Dakace, as in most rural areas in Nigeria, depends on agriculture as a source of livelihood and may therefore be receptive of innovations and technologies which could improve their farming activities.

\section{d) Membership of cooperatives/professional associations}

The importance of group dynamism in effectively discharging some functions or in solving common problems cannot be overemphasized. The respondents in I.A.R are not members of any cooperative society but they all belong to various respective professional associations. In Dakace, about $95 \%$ of the respondents are not members of any association. This implies that the advantages derivable from group dynamics is lacking among the farmers. The introduction of an improved technology to a group may facilitate its acceptance; it also increases awareness as many more people get to be introduced to it at a particular period. Farmers on individual basis may not want to easily accept a new technology like ICT, but as a group the chances of acceptance of such technology increases.

\section{Level of Awareness of ICTs}

Awareness is the first stage in the adoption process. The proportion of the respondents that were aware of the various ICTs is presented in Table 1. The study shows that all the respondents in I.A.R were aware of one or more of the various ICTs. $24.5 \%$ of the respondents were aware of the use of geographical information system (GIS) in analyzing and managing spatial data and mapping out data suitable for particular enterprise production. $13.2 \%$ of the respondents acknowledged that they were aware of the use of global positioning systems to locate and define spatial features for cultivation while $15.1 \%$ of the respondents were aware of the use of yield data base for crop management. Also, about $13.2 \%$ of the respondents were aware of the sale of farm produce through the electronic market (internet). $20.8 \%$ of the respondents were conversant with the use of market information to achieve the marketing functions of buying and selling. $11.3 \%$ were aware of remote sensing technology for detecting and measurement of phenomena against unforeseen outbreaks.

Among farmers on the other hand, about $80 \%$ of the respondents in Dakace acknowledged that they are not aware of the various ICTs. This could be attributed to the low level of education among the farmers and the non-availability of newspaper, internet and other impersonal sources of information. On the other hand, the relative high level of awareness of the IAR staff members may be due to their high level of education as well as the availability of wide range of sources of information. 
The study further shows that majority (70\%) of the respondents that were aware of ICT applied the information sought from the ICT sources on farm level practices such as farm sizes and location, crop spacing, feed formulation and management techniques, soil survey work, irrigation and in knowing the prices of crops and inputs. On the other hand, $30 \%$ of the respondents applied the information obtained through ICT on post production practices such as storage and marketing.

\section{Factors Affecting Awareness and Usage of ICTs}

The result of the multiple linear regression to determine the influence of the respondents' socioeconomic factors on the awareness and usage of ICTs is presented in Table 2. The variables tested were sex, level of education, major occupation, and member of cooperative and sources of information. The result indicates that the coefficient of multiple determinations $\left(\mathrm{R}^{2}\right)$ for the estimated regression model was 0.667 . This shows that about $66.7 \%$ of the total variation in the awareness and usage of ICTs were explained by variations in all the explanatory variables included in the model. The F-ratio was significant at $5 \%$ level, implying that all the explanatory variables included in the model were collectively important in explaining variation in the level of awareness and usage of ICTs.

It was found that sex is directly but insignificantly related to the respondents' level of awareness. This is in line with earlier finding that most technologies developed are gender biased (Kaul, 1991). However, ICTs are not technologies that are gender biased. In this part of the world, women rely more on their husbands for information as they have some restriction in mingling with men other than their husbands.

Educational status was found to be directly related to the respondents' level of awareness and was equally statistically significant at 5\% level of probability. This suggests that respondents with formal education tend to have higher level of awareness. It has been argued that education is considered very important in the acceptance of new practices.

Major occupation was found to be directly related to the respondents' level of awareness although not statistically significant. The possible explanation for this is that respondents in agricultural related occupations tend to match their priority problems and plans with the available technologies to solve their problems than those not in full-time agricultural related occupations.

Membership of association was found to be inversely related to the level of awareness and not statistically significant. The inverse relationship between respondent's membership of association and their level of awareness suggests that the more the respondents belong to an association, the less their level of awareness. This is contrary to the apriori expectation because membership of association is expected to increase the level of awareness of members. This result suggests that the respondents were not enjoying the benefits of group dynamics.

Access to sources of information was directly related to the level of awareness and also was found to be statistically significant. This implies that the respondents make use of the sources of information available to them in receiving information about new technologies.

\section{Problems and Prospects of ICTs}

\section{Problems of ICT Usage.}

A number of problems were enumerated by the respondents as hindering or limiting their application of ICTs. The result presented in Table 3 shows the problems identified by the respondents.

From the analysis, it was found that cost of software and hardware as well as poor access to ICT infrastructure were the major problems faced by the respondents with $20.0 \%$ of the respondents acknowledging that. Also, $17.2 \%$ of the respondents identified problem of poor network and networking. About $11.4 \%$ of the respondents recorded the problems of unstable power supply, poor sensitization about ICT and low computer literacy as affecting ICTs usage. Only about 8.6\% of the respondents complained about few extension agents and services being available to create awareness and guidance for application of ICTs to farmers.

\section{Prospects of ICT Usage}

The respondents that were aware and/or used any of the available ICTs identified a number of advantages emanating from their use. These advantages are shown in Table 4. 
It was found that about $26.3 \%$ of the respondents acknowledged that ICT can broaden the knowledge of the user while $21.1 \%$ of the respondents prospected ease of obtaining relevant information as one of the advantages of the ICTs. About $15.8 \%$ of the respondents were of the view that ICT can reduce drudgery and also it is time effective while about $10.5 \%$ of the respondents acknowledged that ICTs can facilitate the sourcing of cheap and available inputs. About $7.9 \%$ of the respondents accepted that the ICT can facilitate provision of faster and wider markets for products while 5.3\% accept that ICT can improve the farming system generally.

\section{Summary, Conclusion and Recommendation}

The objectives of this study were to assess the problems and prospects and also determine the factors that influence the respondents' level of awareness and application of ICTs among agricultural stakeholders. A set of structured questionnaire was administered to twenty (20) researchers and twenty (20) farmers from I.A.R and Dakace village. The data collected were analyzed using descriptive statistics and simple regression analysis.

The relationship between the respondents' level of awareness and socio-economic characteristics showed that sources of information and educational status of the respondents were related to their level of awareness and were statistically significant at $5 \%$ level of probability. The other variables (sex, membership of association and major occupation) were not significant but had positive relationship with the respondents' level of awareness of ICTs. Most of the respondents that were aware and applied the ICT encountered some problems which include poor network, poor and unstable source of power supply and poor access to ICT infrastructure. On the other hand, some of the respondents enumerated increase in yield, location of available and cheap inputs, improved farming systems and faster and wider markets for products as some of the benefits/prospect of the ICT usage in agriculture.

\section{Conclusion}

The analysis in this study showed that respondents' characteristics are very important determinants of ICT awareness and application. The poor rate of awareness and application of ICT among majority of the farmers is an indication of low sensitization drive, poor extension services and their inaccessibility of ICT infrastructure. The prospect for ICTs usage in agriculture in Nigeria is enormous in view of the fact that the whole world is gradually becoming a global village. Nigeria therefore has no option than joining the technological trend especially if the problems earlier enumerated are solved.

\section{Recommendations}

On the basis of the findings the following recommendations are made:

i. Effort should be made by both governmental and non-governmental ICT organizations (NGOs) in improving the sensitization drive to not only increase awareness but also generate the interest of stakeholders in agricultural sector in application of ICTs.

ii. Improvement on source of power supply. This entails the government creating larger electricity grids with bigger capacity for supply to various parts of the country, including the rural areas. Also through the adoption of the modern solar panel as source of power supply by rural communities can as well minimize this problem especially in rural areas.

iii. Translate the technologies to local languages as well as more training on ICT usage. This would increase the level of computer literacy among the populace.

iv. Improvement on network and networking. Governmental and NGOs can provide a guaranteed Internet Service Provider (ISP) with greater efficiency.

v. The provision of cheap hardware (computers) and software (programs) by the various national ICT organizations will go a long way in ensuring an effective usage of ICTs.

vi. To speedily tackle the shortcomings of poor access to ICT infrastructure, ICT activities should be employed effectively in all sectors of the economy including universities, other tertiary institutions and in research institutes.

vii. ICT workshops and trainings should include farmer education, entrepreneur development and skills acquisition programmes in agriculture, which will assist in market orientation and appropriate technology acquisition and

viiiThe agriculture sector policy should be reviewed by the government to include an ICT dimension analyzing the gaps in applications, particularly in rural societies. 


\section{REFERENCES}

Abdulsalam, Z. (1997). "Socio-economic analysis of the production of selected main crops Involved in cross-border grain trade in Katsina State". An unpublished M.Sc. Thesis, Department of Agricultural Economics and Rural Sociology, A.B.U., Zaria.

Adeniyi, O., Phillipe, C. and Rex, U. (2000). "The Development of Nigerian Agriculture: Suggestions for the Future". Societe General Bank (Nigeria) Limited. Published for Evans Brothers (Nigeria Publishers) Limited.

Adesimi, A.A. (1981). "Farm Management Principles and Decision". Monograph, Department of Agricultural Economics, University of Ife, Ile - Ife.

ALIN-EA (2005). $\mathrm{ICT}_{4} \mathrm{D}$ in Eastern Africa, 2005. (Online): http://www.alin.or.ke/work/ict.asp\# okn.

Ariyo, D. (1999): "Developing a Knowledge Driven Nigerian Economy: An Economic Framework for the $21^{\text {st }}$ Century", Information Technology Revolution of the New Century. pp 29-58.

Boroffice, R.A (2004). Nigeria Sat - 1: A Solution to Sustainable National Development Challenges. "In: Oyinloye, R.O, Agbo, B.F and Aliyu, Z.O. (2004).Application of Nigeria Sat - 1 Data for Land use/ Land cover mapping". pp 20-24

Bregar, L. and Dmitrovic, T. (2004). (Online): Information resource service and management problems. http:// www.ems.ed.ac.uk/Irspmvi/abstracts/bregar dmitrovic78.pdf

Changchui, H. (2004). "Revolutionizing Agriculture through ICT". A Keynote Speech by Assistant Director-general and Regional Representative for Asia and the Pacific, Delivered at the AFITA/WCCA 2004 Conference (Asian Federation of Information Technology in Agriculture and World Congress on Computers in Agriculture), $10^{\text {th }}$ of August.

Danial, B.J. (2006): "The Nigerian Economy in the $21^{\text {st }}$ century: Prospects and Challenges Ahead" An article on the Information technology revolution of the new century . pp 39, 68, 4658.

Fabiyi, Y.L (2004). "Market Information Systems for Sustainable Development in Nigeria". A Keynote Speech Presented at the 2004 Annual
Conference of National Association of Agricultural Economists (NAAE) Held at Ahmadu Bello University, Zaria. $3^{\text {rd }}-5^{\text {th }}$ November.

Isa, S. (2006): "Nigeria must Embrace Reality in Technology Development" Thisday Newspaper. 6th July 2006. pp 34.

Kaul, R.N. (1991). "Development and Extension of Equipment for Rural Farm women: Experiences at IAR". Invited Lecture Delivered at the National Workshop on Extension Strategies for Reaching Rural Women, September 23 - 27.

Kirschner, P and Woperies, R. (2003). "Using Web services to Interoperate Data at the FAO". FAO's Second 60 Years: Evolving Priorities, New Opportunities.

Merriam - Webster, (1993). The Third New International Dictionary of the English Language Unabridged.

Momah, S. (1999). Technology is Power; Memoirs of a Soldier, Scholar, Strategist, Engineer in Government. Spectrum books limited, Ibadan, Nigeria. pp 9 - 133.

Nigerian Defence Academy (NDA), 2001. Facts on Nigeria; Desk Diary.

Oyekanmi, O. (2006): "Increased Relevance for IT in 2006" Thisday Newspaper. $5^{\text {th }}$ January 2006. pp. $31-32$.

Rains, G.C and Thomas, D.L. (2000). "Precision Farming: An Introduction to Technology Based Solutions" in: Basics for a new IT Adoption. pp 8

Umar, M. (1993). "From Research to farmer: The South Pacific Agricultural Information Network". Paper Presented November 10 $12^{\text {th }}, 1993$, Bonn, Germany. International Symposium on New Information Technologies in Agriculture. pp $51-54$.

Voh, J.P. (1981). "The Need for Communication Sources and Awareness of Selected Recommended Farm Practices: A Study in a Village in Kaduna State of Nigeria" African Journal of Agricultural Science, Vol. 8: Nos. 1 \& 2 .

Yusuf, M.O. (2006). "Information and Communication Technology and Education" In: Analyzing the Nigerian National Policy for Information Technology. 
TABLE 1: $\quad$ Distribution of Respondents According to Level of Awareness of ICTs

\begin{tabular}{lccccc}
\hline Technology & \multicolumn{2}{c}{ IAR } & & DAKACE & \\
\cline { 2 - 3 } \cline { 5 - 6 } & No of Respondents & \% & & No of Respondents & \% \\
\hline Geographical information & 13 & 24.5 & 0 & 0 \\
System & 7 & 13.2 & 0 & 0 \\
Global Positioning System & 6 & 11.3 & 0 & 0 \\
Remote Sensing & 8 & 15.1 & 0 & 0 \\
Yield Monitoring Technology & 7 & 13.2 & 0 & 0 \\
E-commerce in Agriculture & 11 & 13.2 & 4 & 20 \\
Market Information System & 1 & & & 16 & 80 \\
No Response & & $\mathbf{1 0 0}$ & $\mathbf{2 0}$ & $\mathbf{1 0 0}$ \\
& & & & \\
\hline Total & $\mathbf{5 3 *}$ & &
\end{tabular}

* Multiple Responses

TABLE 2: $\quad$ Regression Results for the Socio-Economic Factors Affecting Awareness and Usage of ICTs

\begin{tabular}{lccc}
\hline Independent Variable & $\begin{array}{l}\text { Regression } \\
\text { Coefficients }\end{array}$ & $\begin{array}{l}\text { Standard } \\
\text { Error }\end{array}$ & $\begin{array}{c}\text { T } \\
\text { Value }\end{array}$ \\
\hline Constant & -0.178 & 0.265 & -0.671 \\
Sex (X1) & 0.077 & 0.198 & 0.390 \\
Educational Status (X2) & 0.121 & 0.041 & $2.953^{*}$ \\
Major Occupation (X3) & 0.002 & 0.053 & 0.036 \\
Membership of cooperative (X4) & -0.113 & 0.194 & -0.583 \\
Sources of Information (X5) & 0.048 & 0.015 & $3.235^{*}$
\end{tabular}

$\mathrm{R}^{2}=0.667 \mathrm{~F}=13.628 *$ Degree of freedom $=39 *=$ Significance at $5 \%$ level of probability

TABLE 3: $\quad$ Problems Limiting the Usage of ICTs.

\begin{tabular}{clcc}
\hline S/No & \multicolumn{1}{c}{ Problems } & No of Respondents & $\%$ \\
\hline 1 & Unstable power supply & 4 & 11.4 \\
2 & Cost of software and hardware & 7 & 20.0 \\
3 & Poor network and networking & 6 & 17.2 \\
4 & Low computer literacy & 4 & 11.4 \\
5 & Few extension services and agents & 3 & 8.6 \\
6 & Poor access to ICT infrastructures & 7 & 20.0 \\
7 & Poor sensitization about ICT & 4 & 11.4 \\
& & & $\mathbf{1 0 0}$ \\
\hline
\end{tabular}

* Multiple responses for respondents that were aware of ICTs. 
TABLE 4: Distribution of Respondents According to Prospects Identified

\begin{tabular}{clcc}
\hline S/NO & Prospects & No. of Respondents & \% \\
\hline 1 & Increase in yield & 6 & 15.8 \\
2 & Broaden knowledge & 10 & 26.3 \\
3 & Obtain relevant information & 8 & 21.1 \\
4 & Time effective and reduce drudgery & 5 & 13.2 \\
5 & Locate available and cheap inputs & 4 & 10.5 \\
6 & Improve farming systems & 2 & 5.3 \\
7 & Faster and wider markets for products & 3 & 7.9 \\
& & & $\mathbf{1 0 0}$ \\
\hline
\end{tabular}

* Multiple responses for respondents that were aware and applied ICT 